\title{
The utilization of an abandoned mining pond as a retention pond in dealing with stormwater runoff
}

\author{
H. Takaijudin, A. H. A. Shahir \& A. M. Hashim \\ Civil Engineering Department, Universiti Teknologi Petronas, \\ Perak, Malaysia
}

\begin{abstract}
Most abandoned ponds can be upgraded as detention or retention ponds. However, some of the abandoned mining ponds have been used in an improper way such as for illegal landfill sites. The selected ponds in this study fulfil the characteristics as retention ponds in terms of location, pond capacity, inlet and outlet discharges and the facilities installation. Design rainfall was obtained from MASMA manual using Bagan Serai design storm coefficient. The peak flow rate for the drainage system was designed in 10 years ARI due to having the development of housing and industrial areas. The results show that the peak runoff by using design rainfall is much higher than the peak flow from current rainfall. The volume of the pond has been designed for 10,50 and 100 years ARI (Average Recurrence Interval). The storage can be exceeded up to $130000 \mathrm{~m}^{3}$ whereas the availability of this natural pond is up to $156000 \mathrm{~m}^{3}$. Thus it is concluded that the capacity of the ex-mining pond is sufficient to cater for the runoff from catchment areas. The abandoned mining pond has the potential to be developed as part of the infrastructure in future.
\end{abstract}

Keywords: ex-mining pond, retention pond, peak discharges.

\section{Introduction}

Stormwater management tools such as Low Impact Development (LID) or Water Sensitive Urban Design (WSUD) offer a sustainable solution to decentralized stormwater management such as the wet pond which can be implemented in watershed scale [1]. A series of ponds can promote flow attenuation with the installation of outlet structures such as V-Notch weir and orifices [2]. Retention ponds offer water quality and flood control by the natural process in the ponds. 
They provide the most effective storm water treatment practices at removing pollutants. The water contained in the permanent pool mixes with and dilutes the initial polluted runoff from heavy rainfall events. The retention pond also helps plants, algae, and bacteria consume the pollutant for their food and energy to help their growth. Thus, it will reduce the total mass of pollutants released downstream. The abandoned mining pond can be considered for the community event as regional pond facilities. It has the potential to be upgraded as a series of wet pond in some developed areas due to site constraint and economic considerations [2]. The current practice in Malaysia is that the developers and engineers prefer retention facilities to handle runoff from development activities. They can upgrade abandoned ponds to cater for the runoff from residential areas. Most of the natural processes can be adopted using this method. It functions as storage and releases the flow gradually through outlet control structures [3].

Since 1820, tin mining was the most active industry in Malaysia. The mining started after the arrival of hardworking Chinese immigrants, mostly Cantonese and Hakka, who provided the manpower. Tin mining mainly occurred in the West Peninsular of Malaysia and as a result of this activity in that area ex-mining land has covered approximately 113700 ha since the 1930s [4]. The alluvial deposited soil mainly the soil type where tin can be found. The sand is infertile and the area has a harsh microclimate, whereas the slime is more fertile but normally water logged [5]. The state of Perak was the eldest mining pond site. Taiping is the first town where tin was being commercialized and by 1883 , Malaysia had become the largest tin producer in the world. It supplied around $55 \%$ of the world's tin by the end of the $19^{\text {th }}$ Century, compared with $30 \%$ in 1992.

During the 1990s, many mining ponds stopped their operations and were abandoned for a long time. Only 4730 ha $(4.2 \%)$ of the ex-mining land had been utilized for agriculture and $5.5 \%$ for other uses [4]. Although the government included the Act of ex-mining ponds which stated that the rehabilitation of exmining ponds would be used for certain plans. Unfortunately, the plans are still not clear. Narrowing it down to Perak state itself, the mining pond, an abandoned pond is mainly a waste area. Some of the ponds have been deposited with solid waste and become illegal landfill sites. In terms of cost-benefit, it is predicted to be the best detention facility due to natural causes.

The quantity and quality of water needs to be considered for design and analysis of an ex-mining pond. The 10-year (ARI) design storm event is recommended for minor conditions while 50-year ARI for major conditions in controlling peak flow and water quality [6]. For this reason, this paper presents the investigation of the availability of the pond storage to cater for surface water which comes from mixed developments, particularly from residential and industrial areas.

\section{Project area description}

The study area covers Lot 5057, Lot 3873, Lot 7805 and Lot 11979 of Kamunting Raya, Taiping, Perak. It is located in the Larut Matang and Selama 
territory and situated about 10km from Taiping Utara PLUS Toll. The proposed site is still on a development program. The developed area consists of industrial areas which are mainly factories and training centres and some residential areas. The area is about 200 hectares and almost flat ground level. The proposed site has three abandoned mining ponds. Fig. 1 illustrates the satellite image of exmining ponds which are located in the middle of the developed area.

The study has selected one pond which receives the runoff from residential areas and some industrial areas. Fig. 2 demonstrates the drainage network model

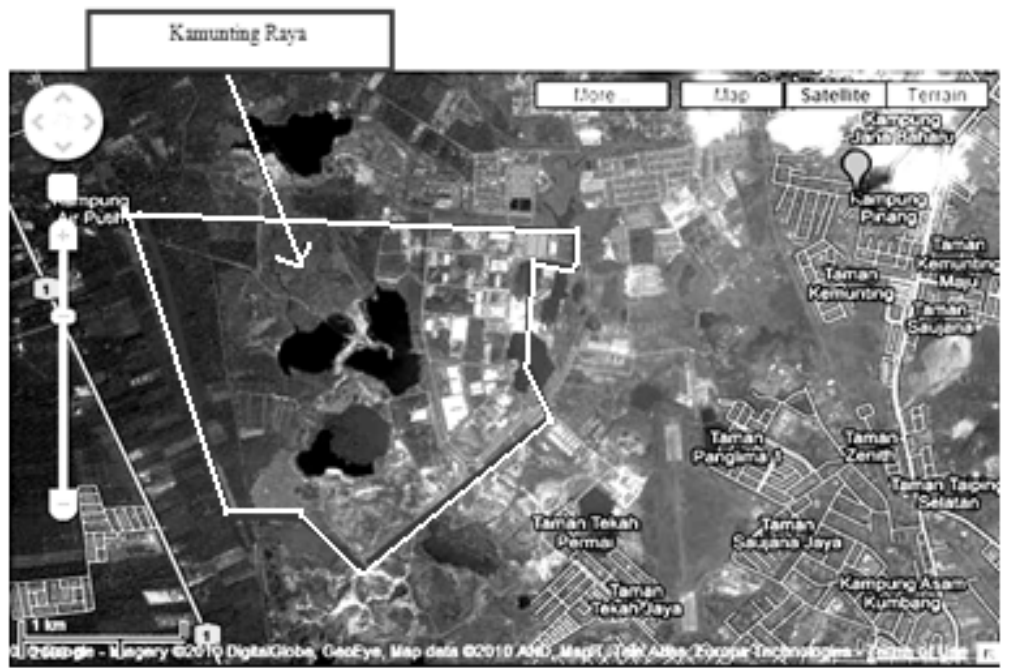

Figure 1: $\quad$ Satellite view of Kamunting Raya area.

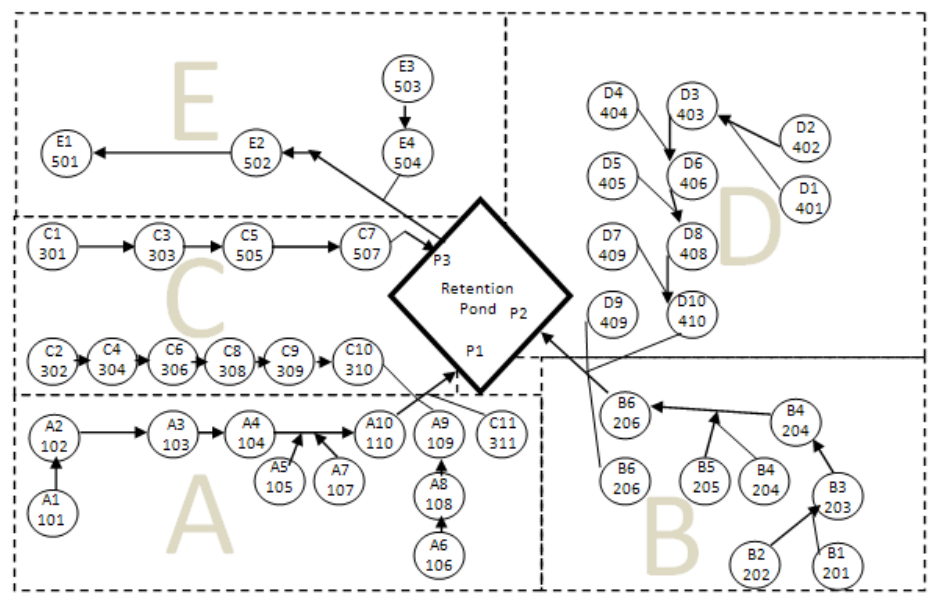

Figure 2: Drainage network with the integrated pond. 
using MIDUSS software at the catchment areas. The drainage areas of Kamunting Raya are connected to each other. There are 3 inlets that cater for runoff from catchment A (59.38 ha), B (29.40 ha), C (58.42 ha) and D (56.11 ha). There is one outlet from the retention pond that is discharged to the block drain e2-e5 in catchment E. However, runoff catchment $E$ has been discharged to another pond which is located at the downstream part. The main drain will cater for the runoff stormwater for the larger area. P1, P2 and P3 are the inlets to the retention pond. The final discharge for the overall area is at Sungai Air Putih, Kamunting, Perak.

\section{Methodology}

\subsection{Data collection}

Data has been collected from various local authorities, developers and consultants for this particular site. 20-years rainfall data from 1989 to 2009 were recorded at JKR Taiping rain gauge. The catchment areas of the site were provided by DID. For specific land in Malaysia, local authority is given the power to control and manage the land. Therefore, for this project some local authorities were consulted for the legal data. Other than that, for the real experience of the site conditions, the consultants and developers have to be consulted.

\subsection{Design criterion}

Rainfall is the main contributor of natural water resources. It flows as surface runoff, infiltrates into the soil and will evaporate. In the design, the rainfall intensity is taken into consideration as solely as the surface runoff. Drainage network was designed for 10 years ARI while the pond system for 100 years ARI. The contribution in design stages is in terms of the rainfall intensity. Intensity (I) can be calculated using eqn (1):

$$
\ln \left({ }^{R} I\right)=a+b \ln (t)+c\left(\ln \left(t^{2}\right)\right)+d\left(\ln \left(t^{3}\right)\right)
$$

where,

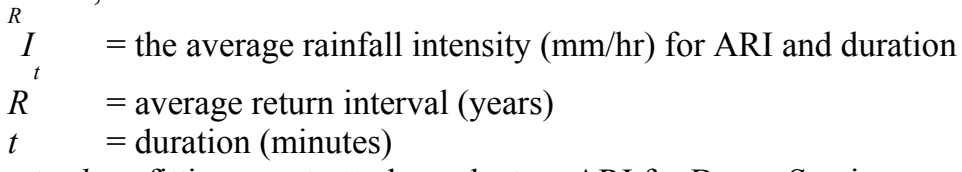

$a$ to $d$ are fitting constants dependent on ARI for Bagan Serai area.

The next step will be on the determination of peak flow by applying the Rational Method. This method is used to estimate the peak flow for each conveyance system. This method was applied to the manual calculations (spreadsheet) and MIDUSS software. Using the same method, the result was expected to give significant output with lower percentage difference. Specific geometry of drainage was selected in order to cater for the peak flow of the drainage system. Once the drainage design was completed, the pond was 
designed using Swinburne Method as recommended by MASMA [2]. In this method, the permissible site discharge (PSD) and Site Storage Requirement were determined. However, MIDUSS configuration has provided a different approach in which based on the final discharge from the inlet pond, the pond was designed with certain geometry. It will provide storage routing, the inflow and the outflow hydrograph of the pond.

\section{Results and discussion}

\subsection{Physical evaluation of ex-mining pond}

A mining pond is a natural pond. The depth is greater than other man-made ponds. The depth of the pond is about $15 \mathrm{~m}$. Therefore, a lot of consideration is carried out. General limitations adapted from MASMA Volume 8 are analyzed to evaluate the physical characteristic of the pond. Table 1 lists the requirements.

Table 1: $\quad$ The physical criteria evaluation of retention pond (adapted from MASMA 2000).

\begin{tabular}{|c|c|c|c|}
\hline \multicolumn{2}{|r|}{ Criteria } & MASMA Requirement & $\begin{array}{l}\text { Kamunting Raya Ex-Mining } \\
\text { Pond }\end{array}$ \\
\hline & Soil Suitability & $\begin{array}{l}\text { - No limitation on soil infiltration } \\
\text { rate but a minimum rate of } 13 \\
\mathrm{~mm} / \mathrm{hr} \text { is recommended. } \\
\text { - Soil with greater clay content or } \\
40 \% \text { greater silt/clay content } \\
\text { shall not be used. }\end{array}$ & $\begin{array}{l}\text { - No limitation of soil } \\
\text { infiltration. } \\
\text { - The soil is consisting of } \\
\text { sandy soil. } \\
\text { - The system use is natural } \\
\text { and no fill material is } \\
\text { utilized. }\end{array}$ \\
\hline 2) & $\begin{array}{l}\text { Depth to } \\
\text { Bedrock, } \\
\text { Water Table, }\end{array}$ & $\begin{array}{l}\text { - All facilities shall be located at } \\
\text { least } 1.5 \mathrm{~m} \text { above the seasonal } \\
\text { high ground water mark, } \\
\text { bedrock (or hardpan) and/or } \\
\text { impermeable layer. }\end{array}$ & $\begin{array}{l}\text { - These criteria have been } \\
\text { implemented. The level of } \\
\text { the building is increase by } \\
2 \mathrm{~m} \text {. }\end{array}$ \\
\hline 3) & $\begin{array}{l}\text { Proximity to } \\
\text { Drinking } \\
\text { Water Wells, } \\
\text { Septic Tanks, } \\
\text { Drain fields, } \\
\text { Building } \\
\text { Foundations, } \\
\text { Structures and } \\
\text { Property Lines }\end{array}$ & $\begin{array}{l}\text { - Infiltration facilities on } \\
\text { commercial and industrial sites } \\
\text { at least } 35 \mathrm{~m} \text { from drinking water } \\
\text { wells, septic tanks or drain fields } \\
\text { and spring used for public } \\
\text { drinking water supplies. } \\
\text { - Infiltration facilities should be } \\
\text { situated at least } 7 \mathrm{~m} \text { down slope } \\
\text { and 50m from building } \\
\text { foundations. }\end{array}$ & 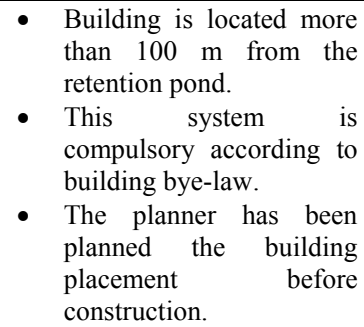 \\
\hline & Land Slope & $\begin{array}{l}\text { - Avoid application of infiltration } \\
\text { practices on a steep grade. } \\
\text { - Infiltration facilities can be } \\
\text { located on slopes up to } 15 \% \\
\text { only. }\end{array}$ & $\begin{array}{l}\text { - The site area is almost flat } \\
\text { whereby the gradient is } \\
\text { approximately } 0.001 \text {. }\end{array}$ \\
\hline 5) & Drainage Area & $\begin{array}{l}\text { Infiltration BMPs are limited in } \\
\text { their ability to accept flows from } \\
\text { larger drainage areas. } \\
\text { - Infiltration basin - maximum of } \\
15 \text { hectares }\end{array}$ & $\begin{array}{l}\text { - The overall catchment } \\
\text { area is about } 200 \text { hectare. } \\
\text { - The catchment area has } \\
\text { been divided according to } \\
\text { the inlet. }\end{array}$ \\
\hline
\end{tabular}


from MASMA and the description from the abandoned mining pond observation in order to comply with the requirements.

\subsection{Hydrologic analysis}

\subsubsection{Rainfall analysis}

For this project, design rainfall is used as suggested by MASMA. The storm duration use is 30 and 60 minutes as suggested. The adjustment factor is used for the time of concentration below 30 minutes. Bagan Serai is chosen for the Design Rainfall as it is the nearest place from Taiping. The drainage network has been designed for 10 years ARI because of the mixed development. The pond has been designed for 50 and 100 years ARI return period. The Malaysian version of MIDUSS has an extra item in the Hydrology menu for design storms for use in Malaysia. Because of the input which uses the same design rainfall, the return period can be chosen to be the same as manual calculation using 10, 50 and 100 years ARI. The default time of concentration is 30 minutes. MIDUSS application is applicable for 2, 5, 10, 20, 50 and 100 years ARI. The design rainfall is used rather than current time series rainfall for MIDUSS application.

The advantage of the time series rainfall data analysis is that the depth is clearly shown according to the return period. However, the analysis method can be too straight forward and the result of the Intensity is much lower than the design rainfall. In addition, 24 hour rainfall duration is too long. Therefore, more comprehensive statistical analysis has to be carried out based on the data. The method used for this project has limitations and further calculations have to be made.

\subsubsection{Peak runoff and pond capacity}

In using manual calculation, the drainage design is adapted using MASMA manual. Two (2) types of Rainfall intensity are used for these design purposes. The first design is using the design storm which is recommended by MASMA and secondly the current rainfall data which has been calculated previously. For a mixed development, the return period of 10 years is required. The time of concentration which has been investigated earlier needed in the calculation using design storm. In the current rainfall calculation, the rainfall intensity is being used directly in the calculation.

Next, the rational method is used for calculating the peak discharge of the drain. The peak discharge is compared to the given drain capacity to determine the real size of the drain. The connected flow of the catchment is taken into account of which in Catchment A there is a link of catchment. The pattern is that the first catchment will have a smaller drain size compared to the last catchment which links to the retention pond. MIDUSS provide different approaches where the hydrograph technique is applied in the model. A percentage of pervious and impervious catchment is specified. The drainage system is design for post development. The percentage of impervious was taken as up to $50 \%$ for Kamunting Raya area. Fig. 3 shows the runoff hydrograph for pervious and impervious areas. 


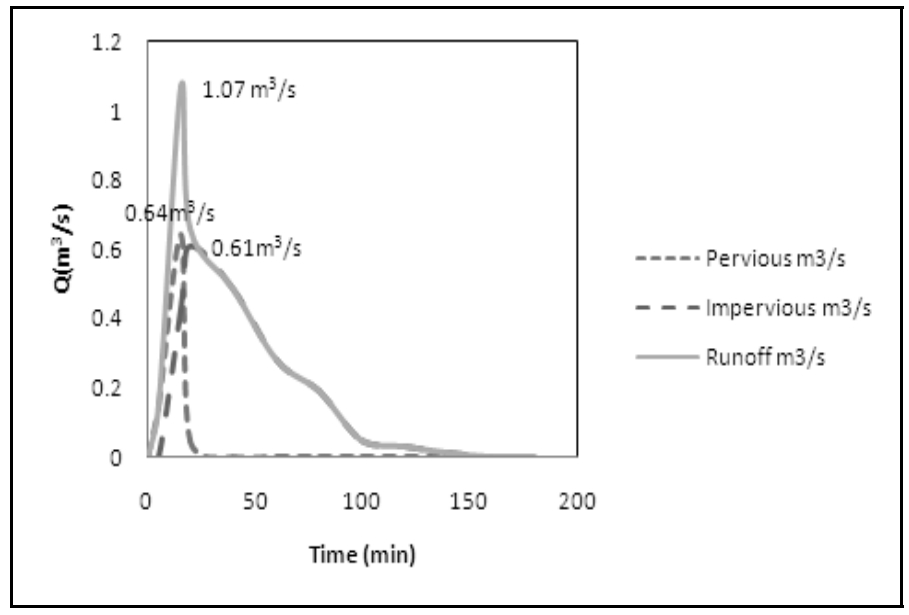

Figure 3: Runoff hydrograph for impervious and pervious areas.

The peak discharges for each drain and the outlet structures have been compared using MASMA manual calculation and MIDUSS software. Figs. 4 and 5 illustrate the difference between values of peak runoff for the selected drain using these two methods. The percentage difference is approximately $4-15 \%$ error by comparing the result of manual calculation and MIDUSS.

For the pond design the volume is calculated based on Permissible Storage Discharge (PSD), the Site Storage Requirement (SSR) and the allowable storage of the existing pond. From the results obtained, the abandoned mining pond is sufficient to cater for the stormwater for the overall catchment. Table 2 lists the capacity of ex-mining pond system for this catchment area. The inlet of the discharge is assumed to be in one inlet. The overall catchment gives a

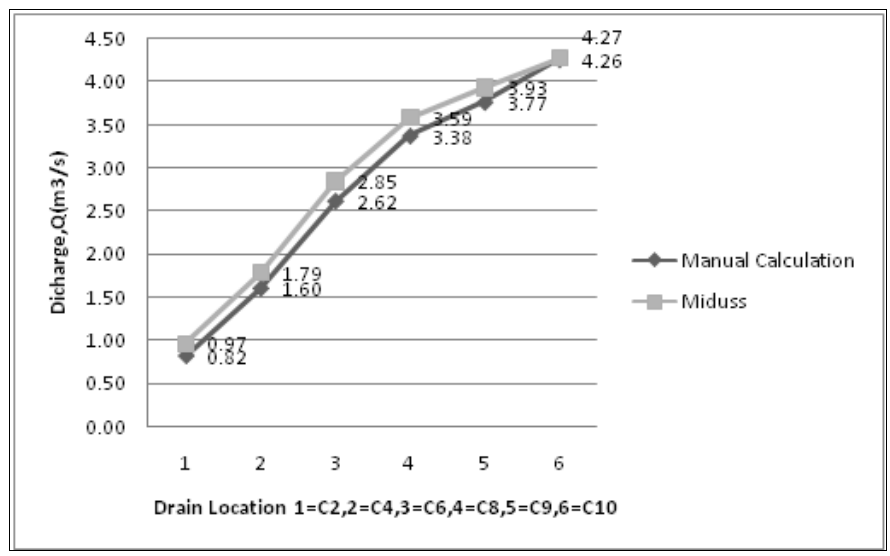

Figure 4: The comparison of peak flow for drainage link C2-C10. 


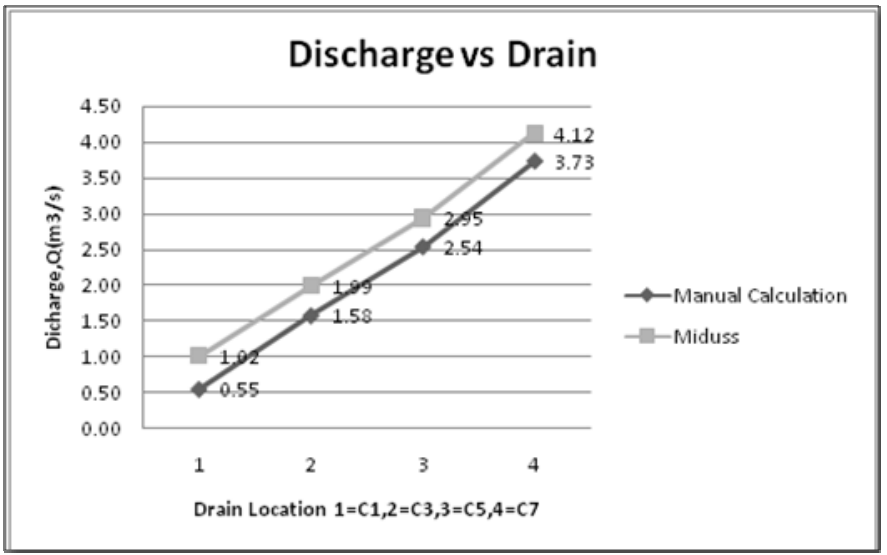

Figure 5: The comparison of peak flow for drainage link C1-C7.

Table 2: $\quad$ Abandoned mining pond capacity.

\begin{tabular}{|c|c|}
\hline & Abandoned Mining Pond \\
\hline $\operatorname{PSD}_{10}(1 / \mathrm{s})$ & 48346.81 \\
\hline $\operatorname{PSD}_{100}(\mathrm{l} / \mathrm{s})$ & 67964.29 \\
\hline $\mathrm{SSR}_{10}\left(\mathrm{~m}^{3}\right)$ & 90435 \\
\hline $\mathrm{SSR}_{100}\left(\mathrm{~m}^{3}\right)$ & 126637 \\
\hline Allowable Storage $\left(\mathrm{m}^{3}\right)$ & 156240 \\
\hline Average Depth of Pond $(\mathrm{m})$ & 5.0 \\
\hline Average Platform Level $(\mathrm{m})$ & GL 8.5464 \\
\hline Average Water Level $(\mathrm{m})$ & IL 7.7297 \\
\hline
\end{tabular}

conventional number of peak discharges for the pond. The pond is designed solely based on the peak discharge that has been calculated. Therefore, the pond volume is higher but still under volume when compare with the volume of the abandoned mining pond. MIDUSS also provide pond design (Fig. 6) and outlet structure such as weir and orifice. There are 2 inflows that produced a higher amount of discharge for 50 year ARI and 100 year ARI as in Figs. 7 and 8 where the allowable outflows are $25.2 \%$ to $65 \%$ respectively, lesser than the inflow. Fig. 9 illustrates the dimension of one of the natural ponds in the study site. However, the depth might vary due to it being a natural pond. The estimated depth of this pond is about $10-15 \mathrm{~m}$ depth approximately. The final discharge is conveyed to the main stream of Sungai Air Putih. 


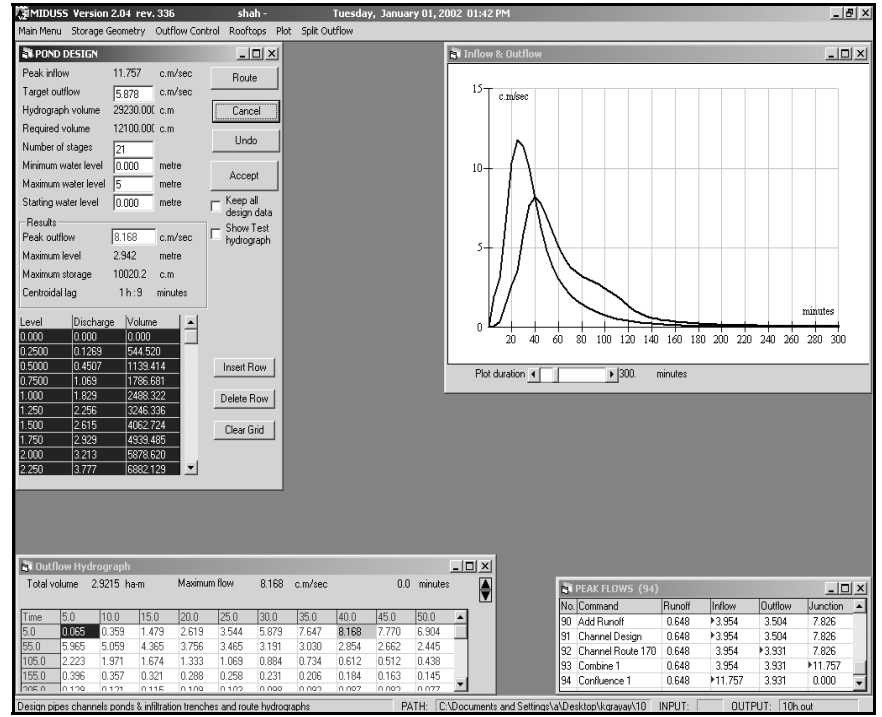

Figure 6: Pond design features by using MIDUSS application.

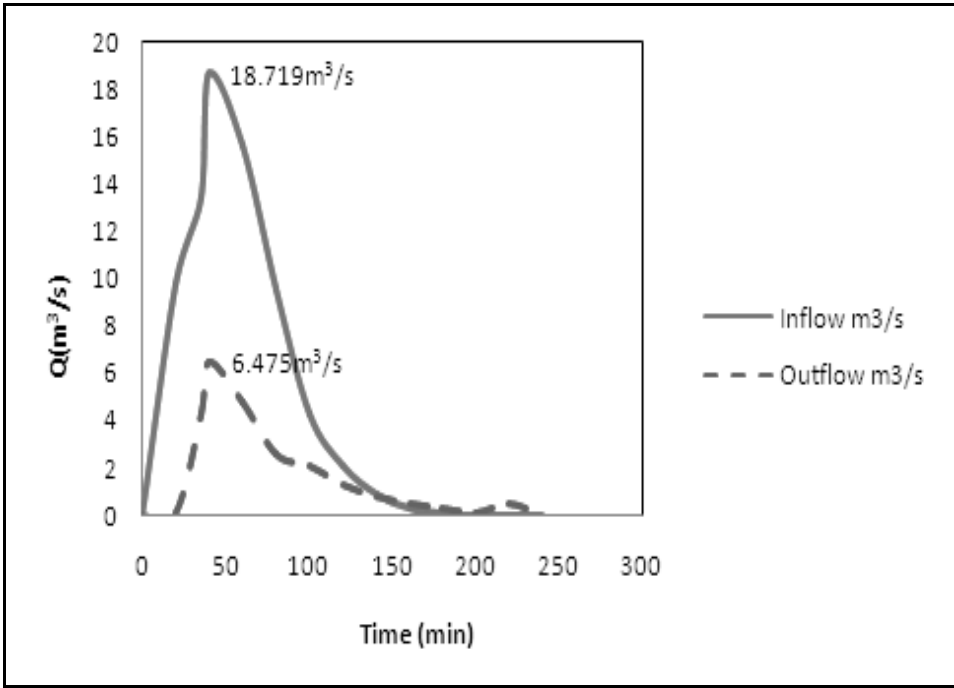

Figure 7: $\quad$ Inflow and outflow for pond system in 50 years ARI. 
36 Flood Recovery Innovation and Response XI

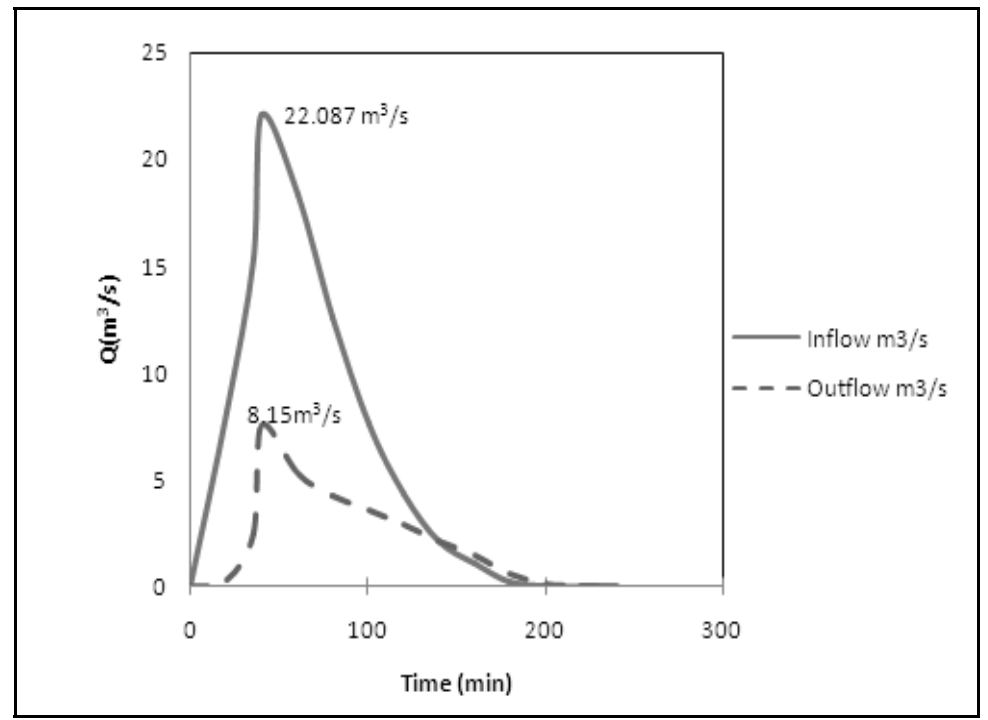

Figure 8: $\quad$ Inflow and outflow for pond system in 100 years ARI.

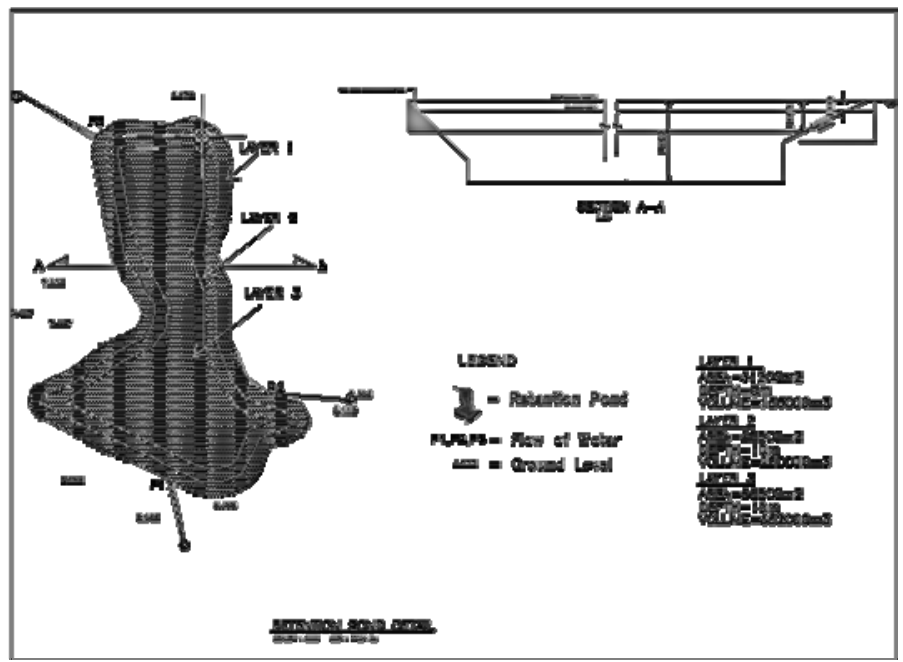

Figure 9: $\quad$ Ex-mining pond layout using ACAD.

\section{Conclusion}

The study confirms that the abandoned pond is suitable to be upgraded as a retention pond due to the location of the pond as it is downstream of the catchment area. Thus all peak runoff can be channelled easily using gravity flow. 
In addition, the capacity of the existing pond is sufficient to cater for the design storm discharge.

The result from MIDUSS and manual calculation produced a very good simulation and it is applicable for analysis of the series of ponds.

The capacity of this pond is that it is sufficient to cater for the higher volume up to a design life of 100 year ARI.

Abandoned mining ponds are usually viewed negatively. It is timely to shift this negative perception to a positive view where with proper planning, proper design of storm water management system, and suitable layout for land use.

Ex-mining ponds will soon be prime real estate masterpieces for the future while generating revenue for the state government.

....With the information available in this case study it is recommended that further study should be made in term of the water quality aspect especially for stormwater treatment.

\section{References}

[1] Roy, A.H., Wenger, S.J., Fletcher, T.D., Walsh, C.J., Ladson, A.R., Shuster, W.D., Thurston, H.W., Brown, R., Impediments and Solutions to Sustainable, Water-Scale Urban Stormwater Management: Lessons from Australia and the United States. Environmental Management, 42(2), pp. 344-359,2008.

[2] Department of Drainage and Irrigation (DID), On-site and Community Retention (Chapter 21) and Regional Retention (Chapter 22), Urban Stormwater Management Manual for Malaysia, 8, 2000.

[3] Takaijudin, H., Hashim, A.M., Vallyutham, K., Shahir, A.H.A., Ghazali, A.H., Implementation of Urban Stormwater Management Practices in Malaysia - A Review, $1^{\text {st }}$ International Conference of Sustainable Building and Infrastructure 2010, Kuala Lumpur, 2010.

[4] Chan, Y.K., The Mining Land - An Overview of the Current Situation in Peninsular Malaysia. Paper presented at the Seminar on Ex-Mining Land and BRIS Soil: prospects and Profits, Kuala Lumpur, p. 17, 1990.

Ho, W.M., Ang, L.H., and Lee D.K., Assessment of Pb Uptake, Translocation and Immobilization in Kenaf (Hibiscus cannabinus L.) for phytoremediation of sand tailings, Journal of Environmental Sciences, 20, pp. 1341-1347, 2008.

[5] Chang, C.K., Ghani, A.A, Zakaria, N.A., Yusof, M.F., Ayub, K.R., Lai, S.H., Hasan, A.M. M., Ainan, A., Rehabilitation of Ex-Mining Pond and Existing Wetland for Integrated Stormwater Management, $11^{\text {th }}$ International Conference on Urban Drainage, Edinburgh, Scotland, UK, pp. 1-10, 2008. 